\title{
Rain Fastness and Persistence of Fungicides for Control of Alternaria Brown Spot of Citrus
}

\author{
A. Vicent, J. Armengol, and J. García-Jiménez, Instituto Agroforestal Mediterráneo, Universidad Politécnica de \\ Valencia, Camino de Vera s/n, 46022 Valencia, Spain
}

\begin{abstract}
Vicent, A., Armengol, J., and García-Jiménez, J. 2007. Rain fastness and persistence of fungicides for control of Alternaria brown spot of citrus. Plant Dis. 91:393-399.

Field persistence and simulated rain experiments were conducted to determine the residual activity and rain fastness of several fungicides used for the control of Alternaria brown spot of citrus. Fungicidal activity persisted well in simulated rain experiments, despite the high rainfall amounts tested ( $40 \mathrm{~mm}$ in 2004 and $90 \mathrm{~mm}$ in 2005). However, most of the fungicides showed a significant reduction of disease control on fruit of 'Fortune' mandarin in the orchard after natural rain in 2004. Fruit growth rate was low and did not appear to play an important role in decline of fungicide residues. Copper products showed longer residual activity on fruit and higher rain fastness than did mancozeb, difenoconazole, iprodione, famoxadone, and pyraclostrobin. $\mathrm{Cu}-$ prous oxide and copper oxychloride SC provided satisfactory disease control on fruit through 28 days and withstood $71 \mathrm{~mm}$ of rainfall in the orchard. A 4-week schedule with copper compounds is proposed for disease control on Fortune fruit during periods of weather favorable for disease development. Respray to replace fungicide deposit seems to be necessary only after heavy or wind-driven rains. With this program, about half of the sprays applied per season for fruit protection could be saved compared with the current schedule in Spain.
\end{abstract}

Additional keywords: formulation, locally systemic, protectant

Alternaria brown spot (ABS) is a severe fungal disease of some mandarins (Citrus reticulata Blanco) and their hybrids in rainy and semiarid citrus-growing areas (33). Susceptibility to ABS is a dominant trait that is transferred from 'Dancy' mandarin to its progeny (11). Dancy mandarin hybrids and some cultivars of unknown origin, such as 'Murcott,' 'Emperor,' and 'Ponkan,' are affected by the disease. The presence of ABS in Spain has become a serious problem for 'Fortune' mandarin (Clementine $\times$ Dancy) production (39), but it also has been observed on other cultivars derived from crosses with Dancy mandarin such as 'Nova,' 'Minneola,' and 'Winola'.

Symptoms of ABS on young leaves are irregular brown necrotic areas with characteristic yellow halos and vein darkening and necrosis. Apices of young shoots are completely defoliated on severely affected trees. Defoliation due to spring infections weakens trees and has an important impact on yield. However, fruit damage causes the most important economic losses. Fruit symptoms include light brown, slightly depressed spots to circular and dark brown

Corresponding author: A. Vicent

E-mail: anvici@eaf.upv.es

Accepted for publication 26 September 2006.

doi:10.1094/PDIS-91-4-0393

(C) 2007 The American Phytopathological Society areas on the external surface. Infected young fruit and leaves often fall and the mature fruit are unmarketable due to the lesions. Leaves are susceptible to the disease until they are fully expanded and hardened. In Florida, Minneola fruit become resistant by midsummer $(9,40)$, but Fortune fruit in Spain are susceptible to infection at all growth stages (39).

The causal agent of ABS was designated originally as Alternaria citri Ellis \& N. Pierce in N. Pierce (21) and later renamed A. alternata (Fr.:Fr.) Keissl. pv. citri, based on the production of a toxin specific to mandarin fruit (27). Later, eight species were described among Alternaria isolates pathogenic to mandarin based on morphological and biochemical traits $(4,25)$. However, all small-spored Alternaria spp. from citrus are closely related by molecular analysis and they have been placed into a single phylogenetic species, A. alternata $(19,20)$.

A. alternata can sporulate on all mature, symptomatic leaves, fruit, or twigs, but sporulates most abundantly on lesions on mature leaves remaining in the canopy (23). Conidia are dispersed aerially and their release is activated by sudden drops in relative humidity and by rainfall (34). When ABS becomes endemic in the orchard, inoculum usually is in excess when susceptible tissue is available and infection is determined mainly by environmental factors (32). Optimum conditions for infection are temperatures from 23 to $27^{\circ} \mathrm{C}$ and 8 to $12 \mathrm{~h}$ of continuous leaf wetness in the form of dew or rainfall $(9,32)$. The lower the temperature, the longer the wetness period that is required for infection. The pathogen produces a host-specific toxin that causes a rapid lesion expansion after 24 to $36 \mathrm{~h}$ of incubation period (9). In Spanish citrus-growing areas, the average temperature is adequate for disease development from late April to October, but infections occur mainly in spring and autumn due to the presence of rain. However, dew or occasional rainstorms also can induce some infections in summer.

Although cultural practices that improve ventilation and prevent the growth of lush foliage can greatly reduce disease severity in the orchard, fungicide applications are essential to produce quality fruit for the fresh market. One or two sprays generally are needed to protect spring flush foliage to reduce defoliation and prevent inoculum build-up. Thereafter, all sprays are applied solely for the control of fruit infections. Copper products and mancozeb are the only fungicides registered in Spain for control of ABS, but QoI, dicarboximide, and triazole fungicides also are recommended in other countries $(18,24,29,31)$. Due to its short incubation period, the control of ABS depends on the protective action of the fungicides rather than postinfectional curative activity. Spray programs have to provide a continual coating of fungicide on susceptible tissues when weather conditions are favorable for infection.

Timmer et al. (32) developed the model Alter-Rater based on the relationships between environmental factors and ABS severity. This model has been effective for timing fungicide sprays in Florida and Brazil $(7,22)$. In a similar manner, growers in Spain are advised to spray when rains or extended dew periods happen simultaneously with temperatures favorable for infection. However, regardless of the disease warning system used, the total number of sprays and the disease control level achieved depend also on the spray frequency during the infection periods. Application intervals that are too long result in severe losses and, with too short intervals, unnecessary sprays are applied. In Spain, growers are advised to spray every 10 to 15 days during the infection periods and respray immediately after a rain to replace the fungicide washed off. However, little information is available concerning 
fungicide rain fastness and persistence under Mediterranean conditions. Elements of weather and expanding tissues are responsible for the physical removal of the fungicide barrier to infection. Fungicides on plant surfaces also are affected by chemical deterioration due to vaporization, photolysis, and hydrolysis (17). Information about the persistence of fungicide deposits on citrus and their resistance to removal by rain can be used to advise effective and environmentally sound application intervals.

The objectives of this study were to (i) evaluate the rain fastness of several fungicides on Fortune fruit and leaf surfaces under simulated rain conditions and (ii) determine their persistence on fruit in the field. This information could allow growers to reduce the number of fungicide sprays during the infection periods or it could increase the number of sprays, but improve ABS control.

\section{MATERIALS AND METHODS}

Fungicides. The fungicides and rates used included the following: mancozeb at $1.87 \mathrm{~g}$ a.i./liter (Dithane M45, 80\% wt/wt WP; Dow AgroSciences, USA), difenoconazole at $0.8 \mathrm{~g}$ a.i./liter (Score 25\%, wt/vol EC; Novartis, Switzerland), iprodione at $0.75 \mathrm{~g}$ a.i./liter (Rovral Aquaflo, 50\% wt/vol SC; Rhône-Poulenc Agro SA, Spain), pyraclostrobin at $0.1 \mathrm{~g}$ a.i./liter (BAS 500-01-F, 24\% wt/vol EC; BASF, Germany), famoxadone at $0.1 \mathrm{~g}$ a.i./liter (Famoxate, 50\% wt/wt WP; Dupont de Nemours, France) copper oxychloride at $1.0 \mathrm{~g}$ a.i./liter (Curenox, 50\% wt/wt WP; IQS S.A., Spain), copper oxychloride at $1.0 \mathrm{~g}$ a.i./liter (Curenox Flow, 70\% wt/vol SC; IQS S.A., Spain), copper hydroxide at $1.0 \mathrm{~g}$ a.i./liter (Hidrocobre Vallés, 50\% wt/wt WP; IQS S.A., Spain), Bordeaux mixture at $1.0 \mathrm{~g}$ a.i./liter (Caldo Bordelés Vallés, 20\% wt/wt WP; IQS S.A., Spain), and cuprous oxide at $1.0 \mathrm{~g}$ a.i./liter (Cobre Rojo Vallés, 50\% wt/wt WP; IQS S.A., Spain). Rates and concentrations of copper compounds are given as metallic $\mathrm{Cu}$. Famoxadone was not tested in the 2004 simulated rainfall experiment on fruit.

Inoculum production. A virulent single-spore isolate of $A$. alternata (AF32002-1) isolated from infected Fortune fruit of Huelva, Spain was used for inoculations. The isolate was stored in $15 \%$ glycerol solution at $-80^{\circ} \mathrm{C}$ into $1.5-\mathrm{ml}$ cryovials. The vials were defrosted at $34^{\circ} \mathrm{C}$ for $30 \mathrm{~min}$ and the fungus transferred to petri dishes with potato dextrose agar (PDA) and incubated at $25^{\circ} \mathrm{C}$ in darkness for 7 days. A suspension containing mycelium and conidia was prepared by pouring sterile water over the colonies and gently rubbing the surface with a sterile glass rod. This suspension was maintained at $4^{\circ} \mathrm{C}$ and used as stock solution. PDA dishes were seeded by spreading 1-ml aliquots of the stock solution and were incubated under a 12-h night-and-day photoperiod (PhilipsTLD18W/33) at $25^{\circ} \mathrm{C}$ for 3 to 4 days. Conidial suspensions were obtained from cultures flooded with distilled water amended with $0.1 \%$ Tween 20 . The surface of the colonies was rubbed gently with a sterile spatula and the suspension was filtered through two layers of cheesecloth to separate mycelium from conidia. Spore concentration was adjusted to $10^{5}$ conidia/ml with a hemacytometer. Suspensions with less than $90 \%$ germination of conidia were discarded.

Simulated rainfall experiments on fruit. Fungicides were applied in a commercial Fortune mandarin orchard on Carrizo citrange (Poncirus trifoliata (L.) Raf. $\times C$. sinensis (L.) Osbeck) rootstock at Ribarroja in Valencia Province, Spain. The trees were 14 years old and planted on a 4by-5-m spacing. The rows ran directly north to south. Each treatment was replicated four times on two-tree plots arranged in a completely randomized design. Guard trees were located between plots within rows and one guard row was located between treated rows. Trees were sprayed to runoff (approximately 10 liters/tree) with a hydraulic sprayer (Mañez y Lozano, Spain) at 3,000 $\mathrm{kPa}$ with two hand-held spray guns. An unsprayed treatment was included as control.

Twenty-four hours after fungicide application, 10 fruit (approximately $30 \mathrm{~mm}$ in diameter) were collected arbitrarily from each plot and transported to the Universidad Politécnica de Valencia (Valencia, Spain) for the simulated rainfall experiments. The rain simulator was composed of two hydraulic nozzles (RA2, Delavan Corp., USA) situated about $3 \mathrm{~m}$ above the fruit placed in a plastic net. Each nozzle operated at a water pressure of $127 \mathrm{kPa}$ and produced droplets with a median diameter of $1 \mathrm{~mm}$ (37). Rainfall distribution under the rain simulator was quantified before the experimental trials and adjusted to $11 \pm 2 \mathrm{~mm} / \mathrm{h}$. This rate corresponds to a moderate rain with a 2 -year recurrence interval estimated from the intensityduration frequency curves for the Valencia weather station (6). Therefore, this type of rainfall has the highest probability of occurring in any 1-year period at this location. Fruit were subjected to $0,10,20$, and $40 \mathrm{~mm}$ of artificial rain $(\mathrm{pH} \mathrm{6.7;} \mathrm{EC} 986$ $\mu \mathrm{S} / \mathrm{cm})$ in 2004 and $0,30,60$, and $90 \mathrm{~mm}$ in 2005. Rain treatments were repeated four times, one for each fungicide plot, and rainfall sequence was assigned randomly within each replicate.

After each rain event, fruit were left under the rainfall simulator to dry. Once fruit were completely dry (minimum of $2 \mathrm{~h}$ ), they were inoculated using a filter paper technique $(28,39)$. Four filter paper squares ( 5 by $5 \mathrm{~mm}$ ) were dipped in the conidial suspension and placed equatorially on the rind of each fruit. Inoculated fruit were incubated in a humid chamber in the dark at $27^{\circ} \mathrm{C}$ and results were evaluated $48 \mathrm{~h}$ after inoculation. The severity of the infection was assessed below each filter paper according to the following scale: $0=$ no necrotic lesions; $1=1$ to 5 lesions; and $2=$ more than 5 lesions observed, lesions coalesced. The disease severity rating for each fungicide treatment was subtracted from that of the nonsprayed, inoculated treatment and the percentage of disease control was used as the response variable. For each fungicide, disease control values were regressed against rainfall amount using the software Statgraphics Plus 5.1 (Statistical Graphics Corp, Englewood Cliffs, NJ, USA).

Simulated rainfall experiments on leaves. Leaf tests were carried out on 3year-old Fortune mandarin trees grafted on Carrizo citrange rootstock. Plants were grown in plastic pots $(20 \mathrm{~cm}$ in diameter by $25 \mathrm{~cm}$ deep) containing potting mix ( $75 \%$ peat, $25 \%$ sand, vol/vol). Potted trees were placed in a greenhouse and completely pruned to force growth of new shoots. When shoots were about $50 \%$ expanded, 16 trees were sprayed with each fungicide to runoff (approximately 0.07 liters/tree) with a manual pressure sprayer (GDM Professional, Di Martino, Italy). A set of 16 nonsprayed trees was included as a control. Twenty-four hours after fungicide application, trees were subjected to 0 , 30,60 , and $90 \mathrm{~mm}$ of artificial rain using the simulator previously described. One plant was used for each fungicide-rain combination. Rain treatments were repeated four times and rainfall sequence was assigned randomly. Ten succulent immature leaves about $3 \mathrm{~cm}$ long were collected arbitrarily from each tree and placed in a plastic net to hold them in place. Leaves were inoculated on the adaxial surface by spraying the conidial suspension with a manual pressure sprayer (GDM Professional) and were placed immediately in a humid chamber. Petioles were immersed into water in the bottom of the humid chamber (9). Inoculated leaves were incubated in the dark at $27^{\circ} \mathrm{C}$ and results were evaluated $48 \mathrm{~h}$ after inoculation. Leaves were photographed by a digital camera (Nikon Coolpix 4500, Nikon Corporation, Japan) at 300 ppi resolution and the percent of leaf area affected was quantified by mean of the Assess software (American Phytopathological Society, St. Paul, MN, USA). For each fungicide, disease control values were regressed against rainfall as described above. Two experiments were conducted during spring 2005.

Persistence experiments. Persistence experiments on fruit were conducted in the same orchard used for simulated rain experiments. Fungicides were applied as described above. Ten fruit (approximately $30 \mathrm{~mm}$ in diameter) were harvested arbitrarily from each plot at $7,14,21$, and 28 days after fungicide application. Each fungicide-harvest date combination was 
replicated four times on two-tree plots arranged in a completely randomized design as described above. A nonsprayed treatment was included as a control. Immediately after each harvest date, fruit were inoculated, incubated, and evaluated following the same procedure described above. For each fungicide, disease control values were regressed against days after fungicide application. Two experiments were conducted in August 2004 and 2005, respectively.

For each experiment, fruit diameter was recorded from 50 fruit arbitrarily selected each week from the experimental plot. Fruit diameter data were regressed against weeks after fungicide application. The slope of the first-order linear regression line was considered as the fruit growth rate. Rainfall, leaf wetness, and temperature were monitored with an automated weather station (Watch Dog Plant Disease Station, Spectrum Technologies, USA) located in the experimental plot.

\section{RESULTS}

Simulated rainfall experiments on fruit. Disease severity in untreated control fruit was $1.40 \pm 0.31$ standard deviation (SD). Linear regression analyses did not indicate that disease control obtained with copper oxychloride SC, Bordeaux mixture, and mancozeb diminished significantly with the increased amount of artificial rain in either of the two experiments (Fig. 1B, D, and F). Nevertheless, disease control levels obtained with mancozeb in the absence of rain were low: $75 \%$ in 2004 and less than $85 \%$ in 2005. Cuprous oxide, copper hydroxide, and difenoconazole showed a significant negative linear relationship between disease control and the amount of artificial rain applied in 2004, but not in 2005 (Fig. 1C, E, and G). However, slopes obtained in 2004 were greater than -0.5 in all three cases; therefore, the reduction in disease control with the maximum amount of rainfall tested (40 $\mathrm{mm}$ ) was less than $20 \%$. Disease control obtained with difenoconazole in the absence of rain was lower in 2004 (78.7\%) than in 2005 (94.4\%) (Fig. 1G). Copper oxychloride WP and pyraclostrobin showed a significant negative linear relationship between disease control and the amount of artificial rain applied in both experiments (Fig. 1A and J). Famoxadone was tested only in 2005 and showed a similar relationship (Fig. 1I). However, disease control levels predicted by the models for the maximum rainfall tested (40 $\mathrm{mm}$ in 2004 and $90 \mathrm{~mm}$ in 2005) were still greater than $70 \%$ in all of the above cases. Iprodione showed a negative exponential relationship between disease control and the amount of artificial rain applied in both experiments (Fig. 1H). The models showed a sharp reduction in the level of control with $10 \mathrm{~mm}$ of artificial rain, after which disease control remained constant at about 60 to $70 \%$.
Simulated rainfall experiments on leaves. Percent leaf area affected in untreated control plants was $51.8 \pm 16.2$ SD. For each fungicide, data from two experiments were combined because no heterogeneity in variances was detected with a two-tailed $F$ test. Only mancozeb and iprodione showed a significant $(P<0.05)$ negative linear relationship between disease control and the amount of artificial rain applied (Table 1). However, slopes were small $(-0.135$ and -0.159 , respectively) and the predicted disease control for the maximum rainfall tested $(90 \mathrm{~mm})$ was over $79 \%$ for iprodione and $87 \%$ for mancozeb.

Persistence experiments. Daily average temperature was $24.6 \pm 2.0^{\circ} \mathrm{C} \mathrm{SD}$ in 2004 and $23.9 \pm 1.3^{\circ} \mathrm{C} \mathrm{SD}$ in 2005 . A total of $188 \mathrm{~h}$ of leaf wetness was recorded during 2004 and $258 \mathrm{~h}$ during 2005 (Fig. 2). In all, $71 \mathrm{~mm}$ of rain fell from 22 to 28 days after fungicide application in 2004. No rain was recorded during the 2005 experiment. The increase in fruit diameter was $1.76 \mathrm{~mm} /$ week in $2004\left(R^{2}=0.864, P=\right.$ $0.022)$ and $2.16 \mathrm{~mm} /$ week in $2005\left(R^{2}=\right.$ $0.927, P=0.037)$. Disease severity in
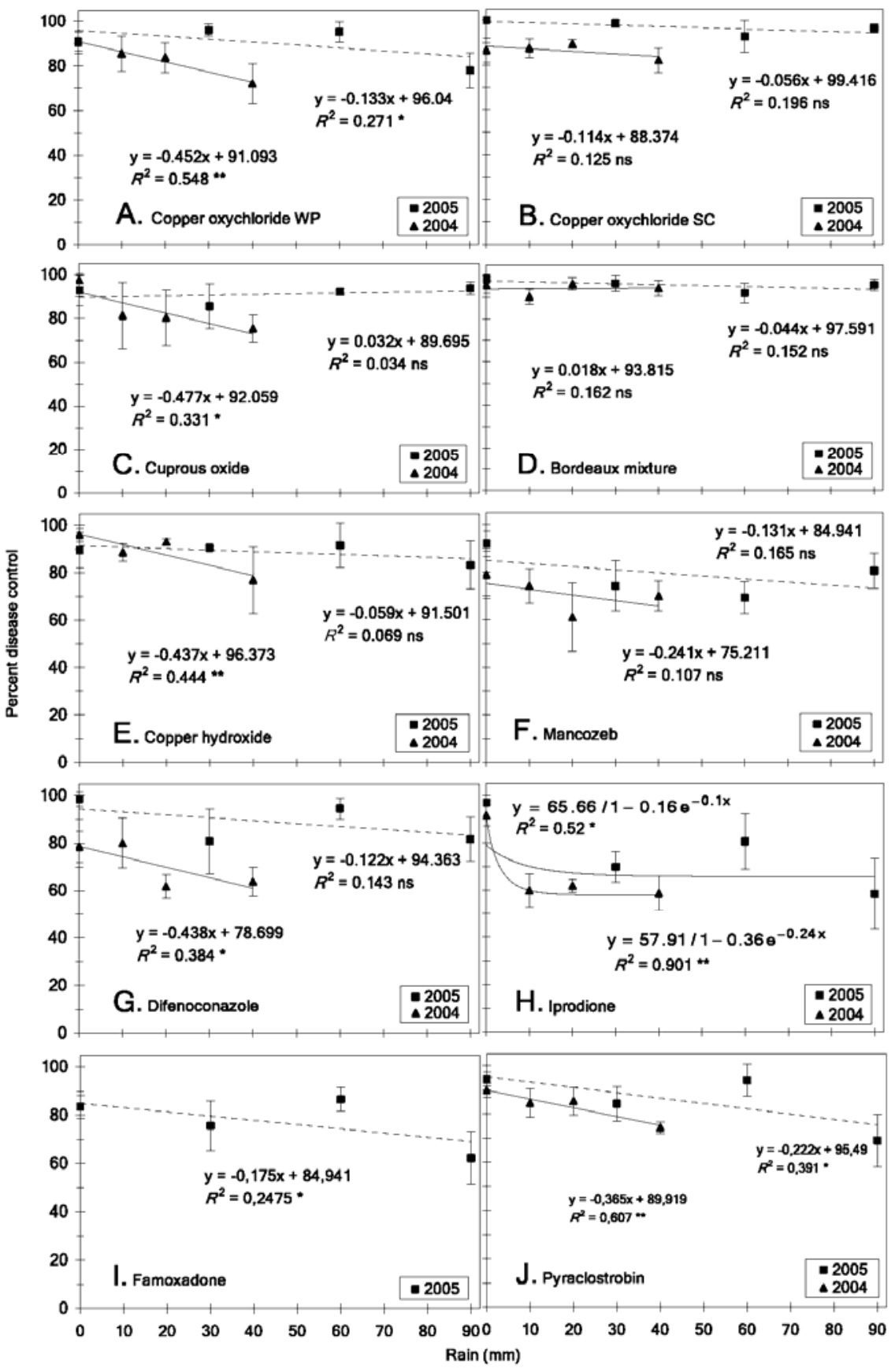

Fig. 1. Effect of simulated rain on Alternaria brown spot control in 'Fortune' fruit with several fungicides. The solid line represents the regression line for 2004 experiment and the dashed line for 2005 experiment (ns $=$ not significant, $*=P<0.05$, and $* *=P<0.01$ ). Disease control values correspond to the mean of 40 fruit with four inoculation points each. Bars represent the standard deviation of the mean. 
untreated control fruit was $1.38 \pm 0.34$ SD. Disease control obtained with cuprous oxide declined significantly with time in 2004 (Fig. 3C). However, the disease control level predicted by the model 28 days after application was over $80 \%$. There was no significant effect of time in the 2005 experiment. Disease control obtained with copper oxychloride $\mathrm{SC}$ declined significantly with time in both experiments (Fig. 3B). The decay rate was more rapid in 2004 than in 2005 and the predicted disease control level 28 days after application was $68.4 \%$ in 2004 and $85.3 \%$ in 2005. In 2004, copper oxychloride WP, Bordeaux mixture, and copper hydroxide showed a nonlinear relationship between decline cide application. Disease control tended to decline slightly from 14 days after the spray and dropped drastically by 21 days after spraying. In 2005, regression analyses did not indicate that disease control diminished with time after fungicide spraying for up to 28 days (Fig. $3 \mathrm{~A}, \mathrm{D}$, and E). Disease control obtained with mancozeb and difenoconazole in the 2005 experiment remained constant for in disease control and time after fungi-

up to 21 days after fungicide application, showing a slight decline afterward. In 2004, disease control dropped drastically from 14 days after spraying with difenoconazole and from 21 days after spraying with mancozeb (Fig. $3 F$ and G). Iprodione showed a negative linear relationship between disease control and time in 2004. The decay rate obtained was -3.7 and the predicted level of disease control 28 days after spray was less than $20 \%$. In 2005, disease control remained constant until 21 days after fungicide application, declining drastically afterwards (Fig. 3H). Famoxadone and pyraclostrobin showed a similar behavior in 2004. Disease control dropped sharply between 14 and 21 days after spraying, with a predicted disease control level $4.3 \% 28$ days after spraying with famoxadone and $0.37 \%$ with pyraclostrobin (Fig. 3I and J). Both fungicides showed a significant negative linear relationship between disease control and time after spraying in 2005 . The intercept and the slope parameters obtained in the regression equations were similar and the predicted disease control levels 28 days after spraying fell between $50 \%$ and $60 \%$.

Table 1. Regression analyses of the effect of simulated rain on Alternaria brown spot control on 'Fortune' mandarin leaves with several fungicides

\begin{tabular}{lcccc}
\hline & \multicolumn{4}{c}{ Regression terms $^{\mathbf{a}}$} \\
\cline { 2 - 5 } Fungicides & Intercept & Slope & $\boldsymbol{R}^{\mathbf{2}}$ & $\boldsymbol{P}$ \\
\hline Bordeaux mixture & 86.114 & 0.097 & 0.103 & 0.263 \\
Copper hydroxide & 97.468 & -0.051 & 0.093 & 0.252 \\
Copper oxychloride SC & 86.745 & 0.032 & 0.017 & 0.633 \\
Copper oxychloride WP & 84.090 & 0.021 & 0.004 & 0.810 \\
Cuprous oxide & 95.575 & 0.010 & 0.007 & 0.750 \\
Difenoconazole & 95.163 & 0.015 & 0.019 & 0.608 \\
Famoxadone & 78.502 & 0.080 & 0.056 & 0.376 \\
Iprodione & 93.825 & -0.159 & 0.392 & 0.009 \\
Mancozeb & 99.462 & -0.135 & 0.523 & 0.001 \\
Pyraclostrobin & 92.817 & 0.079 & 0.180 & 0.115 \\
\hline
\end{tabular}

${ }^{\text {a }}$ Combined data from two experiments.

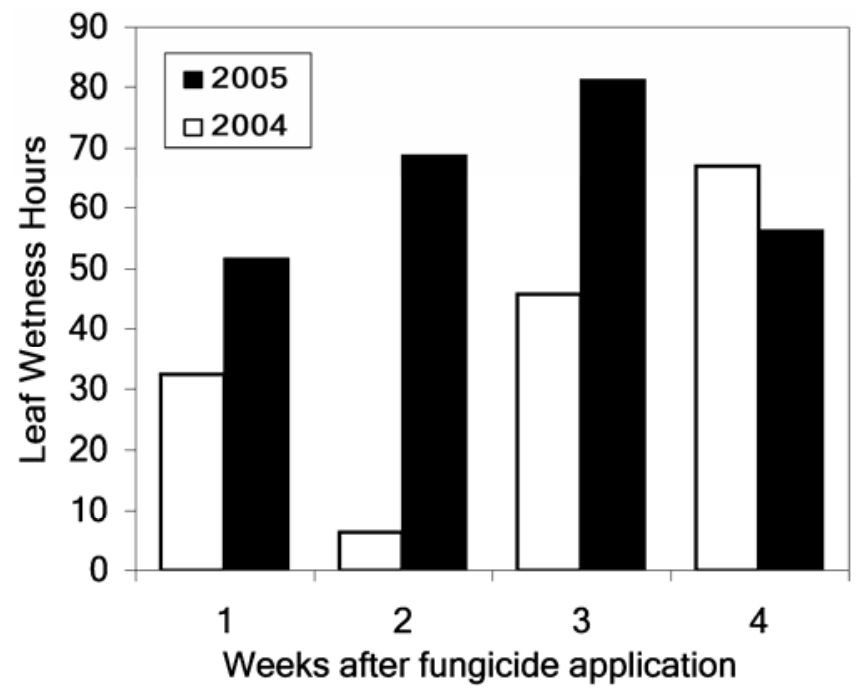

Fig. 2. Number of leaf wetness hours recorded between weekly measurement periods during fungicide persistence experiments.

\section{DISCUSSION}

Rain is known as one of the main weather factors that affects the persistence of fungicides on fruit and leaf surfaces (17). However, in our simulated rainfall experiments, fungicide activity on Fortune fruit and leaf surfaces was not greatly reduced despite the high rainfall amounts tested $(40 \mathrm{~mm}$ in 2004 and $90 \mathrm{~mm}$ in 2005). Only iprodione in fruit experiments showed the typical exponential relationship between rainfall and decay of fungicide deposits $(8,13,17,26)$. This difference could be attributable to the nature of the response variable used to develop the models. Exponential loss models usually express fungicide activity in terms of fungicide residue, whereas our models expressed activity in terms of disease control.

In the 2004 field persistence experiment, most of the fungicides showed a loss of disease control between 21 and 28 days after spraying. A total of $71 \mathrm{~mm}$ of rain fell during that week, which could have had an important effect on fungicide deposits. Time passed between fungicide spraying and onset of rain seemed to account for a substantial amount of the variation in decay rates between simulated rain and persistence experiments. In simulated rainfall experiments, rain regimes were applied 1 day after fungicide spraying. However, in the 2004 field persistence experiment, the first rain was recorded 22 days after fungicide application. The longer time that elapsed between spraying and rainfall in persistence experiments could have allowed other variables to reduce the fungicide residue level. The discrepancy between the two studies also may lie in the difference between simulated rain and natural rain in the orchard. Although rain intensity and duration were adjusted to simulate a natural rain under the condition in east-central Spain (6), summer storms in that region usually are accompanied by strong winds. The combined effect of rain and wind in natural rainfall could result in a greater washing effect than the simulated rain. The chemical composition of the rain also may have affected the results.

Expanding plant surfaces create unprotected areas in the protective coating of fungicide and can dislodge fungitoxic residues that were present (17). In studies carried out in Florida, fruit growth was one of the main factors associated with the loss of effectiveness of copper sprays against melanose caused by Diaporthe citri F. A. Wolf on grapefruit $(2,36)$. Although Florida and Spain are both considered subtropical regions, annual heat unit accumulation in Florida is much greater than in Spain (12). Therefore, fruit growth rates recorded in our persistence experiments were lower than in Florida and seemed to play a minor role in fungicide residue decline. Citrus leaves expand rapidly during a flush of growth and new tissue continues to appear until the shoots are mature. Im- 
mature leaves are highly susceptible to ABS and foliar tissues can be severely affected if weather conditions are favorable for infection. Therefore, although fungicides showed a high rain fastness in the leaf experiments, the development of new tissue may be a more important factor in the control of foliar infection than fungicide tenacity. Thus, our results cannot be used in timing fungicide sprays during the spring, when the main goal is to protect the young foliage to reduce leaf abscission and avoid inoculum build-up.

Cuprous oxide and copper oxychloride $\mathrm{SC}$ showed the longest residual activity in the persistence experiments. The other copper products tested showed a sharp decline in disease control from 21 to 28 days after spraying after $71 \mathrm{~mm}$ of rain. However, all performed well in the 2005 experiment, when no rain was recorded. Because all the copper products were applied in the same manner and at the same rate of metallic $\mathrm{Cu}$ ( $1 \mathrm{~g}$ a.i./liter), differences in disease control can only be attributable to the type of compound or formulation used. In the 2004 experiment, the concentrated suspension formulation of copper oxychloride resulted in longer residual disease control than the wettable powder. Similar differences have been found with sulfur and dithiocarbamate fungicides (16). Apparently, the small average particle size and some specific constituents provide better rain fastness and efficacy with the SC formulations. However, liquid copper fungicides were less effective than dry formulations in the control of melanose on grapefruit in Florida (35). Furthermore, in our experiments, cuprous oxide showed long residual activity in both years, even though it was used as wettable powder. Although copper products are prone to cause rind stippling and darkening of blemishes (3), no phytotoxic effect due to copper was observed in any of our experiments.

The persistence of mancozeb was not superior to copper products in either year. In all, $60 \%$ of disease control activity was lost during the rainy week in the 2004 experiment. This concurs with the results of Suheri and Latin (30), who demonstrated that retention of mancozeb deposits on muskmelon leaves was diminished greatly by wet regimes. Although mancozeb has been used extensively in South Africa for ABS control primarily to avoid copper damage during hot-weather seasons, it was not highly effective for ABS control in Brazil $(22,24,31)$.

Difenoconazole, iprodione, famoxadone, and pyraclostrobin showed shorter residual activity than copper products and mancozeb in both years. This result was initially unexpected because dicarboximides, QoI, and triazole fungicides show locally systemic or translaminar activity. They are able to penetrate into leaf and fruit tissues and, consequently, their fungi- cidal effect should be less affected by weathering $(1,5,10,14)$. However, due to the rapid action of the toxin produced by germinating conidia, ABS control by these products probably is based entirely on the effect against the germinating conidia provided by the external fungicide deposits. Perhaps, weather factors may reduce the external fungicide deposits more in locally systemic ones than in truly protectant fungicides, such as copper products, but no measurement of external residue dynamics were conducted in this study. Rainfall would not appear to explain the shorter residual effect in 2004 because no rain was recorded until 22 days after spraying. However, fewer leaf wetness hours were recorded during this period in 2004 than in 2005 due to sunny weather with low relative humidity. This may have led to increased photolysis or vaporization of fungicide deposits. On the other hand, some specific traits of Fortune mandarin fruit, such as the thinness and high permeability of the cuticle (38), could explain the short residual activity
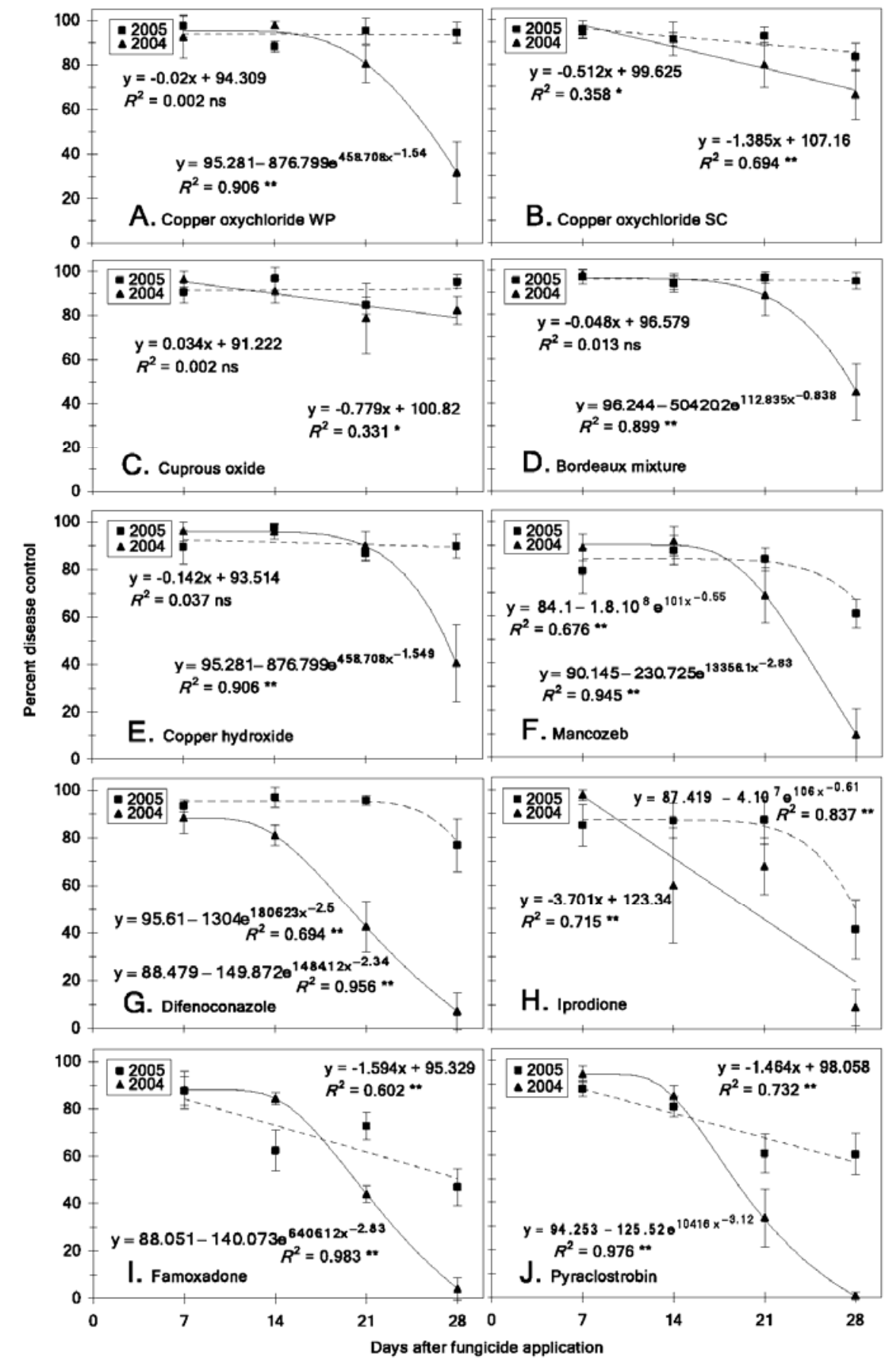

Fig. 3. Persistence of Alternaria brown spot control in 'Fortune' fruit with several fungicides. The solid line represents the regression line for 2004 and the dashed line for the one for 2005 (ns = not significant, $*=P<0.05$, and $* *=P<0.01)$. Disease control values are the mean of 40 fruit ratings with four inoculation points each. Bars represent the standard deviation of the mean. 
obtained with the locally systemic fungicides.

In our study, fungicides were applied to the point of runoff to assure a complete coverage of fruit and leaves. However, under commercial orchard conditions, performance failures of pesticide sprays often result from poor application leading to insufficient coverage (15). Locally systemic fungicides are able to redistribute within the waxy layer or epidermal cells by lateral diffusion, and this makes them less dependent on spray coverage (14). Thus, these fungicides could achieve better control than protectants under poor coverage conditions. As a result of their mobility, locally systemic fungicides also could be more effective than protectants for ABS control on rapidly expanding plant surfaces, such as leaves and young shoots, but nothing has been published in this regard. Furthermore, those products are not registered in Spain and they are known to develop fungal resistance. Thus, they must be mixed or alternated with protectant fungicides.

In conclusion, no advantage was derived from the use of locally systemic fungicides for ABS control on Fortune fruit under conditions in east-central or eastern Spain. Copper products showed longer residual activity and higher rain fastness than the other fungicides tested. Cuprous oxide and copper oxychloride SC provided satisfactory disease control on Fortune fruit through 28 days and withstood $71 \mathrm{~mm}$ of natural rainfall in the orchard. Normal practice in Spain for ABS control on fruit is to follow a 2-week spray schedule with copper compounds or mancozeb during the infection periods and respray immediately after any rain to replace the fungicide deposit. We propose to follow a 4week schedule during those infection periods using copper compounds, mainly cuprous oxide or copper oxychloride SC, and respray only after heavy or winddriven rains. Proper selection and use of equipment are critical to improve coverage and efficacy with these products. With the proposed program, approximately half of the current fungicide sprays applied per season for fruit protection could be saved, reducing the economic and environmental costs of disease control. However, this spray schedule may be not adequate to protect the spring flushes. Significant amounts of unprotected foliage could develop during the 4week interval between successive fungicide applications. Locally systemic fungicides could be more appropriate to control ABS on leaf flushes, but more work is needed to confirm their performance on expanding leaves.

\section{ACKNOWLEDGMENTS}

This research was partially supported by Industrias Químicas del Vallés S.A. (IQV S.A.), Dupont Ibérica S.L., and Asociación de Citricultores de la Provincia de Huelva. We thank F. Alfaro-Lassala, F.
Cuenca (Consellería de Agricultura, Pesca y Alimentación de la Generalitat Valenciana), M. A. Nogueroles, and R. Campillo for their assistance in performing the experiments; J. M. Rodríguez for assistance in the assembly of the rain simulator; REVA S. A. for use of their orchards; and L. W. Timmer (CREC-IFAS/University of Florida) and N. A. Peres (GREC-IFAS/University of Florida) for reviewing the manuscript.

\section{LITERATURE CITED}

1. Adaskaveg, J. E., and Ogawa, J. M. 1994. Penetration of iprodione into mesocarp fruit tissue and suppression of gray mold and brown-rot of sweet cherries. Plant Dis. 78:293296.

2. Albrigo, L. G., Beck, H. W., Timmer, L. W., and Stover, E. 2005. Development and testing of a recommendation system to schedule copper sprays for citrus disease control. J. ASTM Int. 2:1-12.

3. Albrigo, L. G., Timmer, L. W., Townsend, K., and Beck, H. W. 2006. Copper fungicides residue for disease control and potential for spray burn. Proc. Fla. State Hortic. Soc. 110:67-70.

4. Andersen, B., Hansen, M. E., and Smedsgaard, J. 2005. Automated and unbiased image analyses as tools in phenotypic classification of small-spored Alternaria spp. Phytopathology 95:1021-1029.

5. Andrieu, N., Genet, J. L., Jaworska, G., and Bompeix, G. 2000. Behaviour of famoxadone deposits on grape leaves. Pest Manage. Sci. 56:1036-1042

6. Anonymous. 2003. Curvas de intensidadduración-frecuencia. Instituto Nacional de Meteorología, Ministerio de Medio Ambiente.

7. Bhatia, A., Roberts, P. D., and Timmer, L. W. 2003. Evaluation of the Alter-Rater model for timing of fungicide applications for control of Alternaria brown spot of citrus. Plant Dis. 87:1089-1093.

8. Bruhn, J. A., and Fry, W. E. 1982. A mathematical model of the spatial and temporal dynamics of chlorothalonil residues on potato foliage. Phytopathology 72:1306-1312.

9. Canihos, Y., Peever, T. L., and Timmer, L. W. 1999. Temperature, leaf wetness, and isolate effects on infection of Minneola tangelo leaves by Alternaria sp. Plant Dis. 83:429-433.

10. Dahmen, H., and Staub, T. 1992. Protective, curative, and eradicant activity of difenoconazole against Venturia inaequalis, Cercospora arachidicola, and Alternaria solani. Plant Dis. 76:774-777.

11. Dalkilic, Z., Timmer, L. W., and Gmitter, F. G. 2005. Linkage of an Alternaria disease resistance gene in mandarin hybrids with RAPD fragments. J. Am. Soc. Hortic. Sci. 130:191195.

12. Davies, F. S., and Albrigo, L. G. 1994. Citrus. CAB International, Wallingford, UK.

13. Elliott, V. J., and Spurr, H. W. 1993. Temporal dynamics of chlorothalonil residues on peanut foliage and the influence of weather factors and plant growth. Plant Dis. 77:455-460.

14. Evans, E. 1977. Efficient use of systemic fungicides. Pages 199-239 in: Systemic Fungicides. R. W. Marsh, ed. Longman, London.

15. Juste, F., Sánchez, S., Ibañez, R., Val, L., and García, C. 1990. Measurement of spray deposition and efficiency of pesticide application in citrus orchards. J. Agric. Eng. Res. 46:187196.

16. Kudsk, P., Mathiassen, S. K., and Kirknel, E. 1991. Influence of formulations and adjuvants on the rainfastness of maneb and mancozeb on pea and potato. Pestic. Sci. 33:57-71.

17. Lukens, R. J. 1971. Chemistry of Fungicidal Action. Springer-Verlag, Berlin.

18. Miles, A. K., Willingham, S. L., and Cooke, A. W. 2005. Field evaluation of a plant activator, captan, chlorothalonil, copper hydroxide, iprodione, mancozeb and strobilurins for the control of citrus brown spot of mandarin. Aust. Plant Pathol. 34:63-71.

19. Peever, T. L., Carpenter-Boggs, L., Timmer, L. W., Carris, L. M., and Bhatia, A. 2005. Citrus black rot is caused by phylogenetically distinct lineages of Alternaria alternata. Phytopathology 95:512-518.

20. Peever, T. L., Su, G., Carpenter-Boggs, L., and Timmer, L. W. 2004. Molecular systematics of citrus-associated Alternaria species. Mycologia 96:119-134.

21. Pegg, K. G. 1966. Studies of a strain of Alternaria citri Pierce, the causal organism of brown spot of Emperor mandarin. Qld. J. Agric. Anim. Sci. 23:15-28.

22. Peres, N. A., and Timmer, L. W. 2006. Evaluation of the Alter-Rater model for spray timing for control of Alternaria brown spot on Murcott tangor in Brasil. Crop Prot. 25:454-460.

23. Reis, R. F., de Goes, A., Mondal, S. N., Shilts, T., Brentu, F. C., and Timmer, L. W. 2006. Effect of lesion age, humidity, and fungicide application on sporulation of Alternaria alternata, the cause of brown spot of tangerine. Plant Dis. 90:1051-1054.

24. Schutte, G. C., and Beeton, K. V. 1994. The use of triazoles to control Alternaria brown spot of Minneola tangelo in the winter rainfall region of South Africa. Citrus J. 4:19-20.

25. Simmons, E. G. 1999. Alternaria themes and variations (226-235) - Classification of citrus pathogens. Mycotaxon 70:263-323.

26. Smith, F. D., and Machardy, W. E. 1984. The retention and redistribution of captan on apple foliage. Phytopathology 74:894-899.

27. Solel, Z. 1991. Alternaria brown spot on Minneola tangelos in Israel. Plant Pathol. 40:145147.

28. Solel, Z., and Kimchi, M. 1997. Susceptibility and resistance of citrus genotypes to Alternaria alternata pv. citri. J. Phytopathol. 145:389-391.

29. Solel, Z., Oren, Y., and Kimchi, M. 1997. Control of Alternaria brown spot of Minneola tangelo with fungicides. Crop Prot. 16:659664.

30. Suheri, H., and Latin, R. X. 1991. Retention of fungicides for control of Alternaria leaf blight of muskmelon under greenhouse conditions. Plant Dis. 75:1013-1015.

31. Swart, S. H., Wingfield, M. J., Swart, W. J., and Schutte, G. C. 1998. Chemical control of Alternaria brown spot on Minneola tangelo in South Africa. Ann. Appl. Biol. 133:17-30.

32. Timmer, L. W., Darhower, H. M., Zitko, S. E., Peever, T. L., Ibanez, A. M., and Bushong, P. M. 2000. Environmental factors affecting the severity of Alternaria brown spot of citrus and their potential use in timing fungicide applications. Plant Dis. 84:638-643.

33. Timmer, L. W., Peever, T. L., Solel, Z., and Akimitsu, K. 2003. Alternaria diseases of citrus-novel pathosystems. Phytopathol. Mediterr. 42:99-112.

34. Timmer, L. W., Solel, Z., Gottwald, T. R., Ibañez, A. M., and Zitko, S. E. 1998. Environmental factors affecting production, release, and field populations of conidia of Alternaria alternata, the cause of brown spot of citrus. Phytopathology 88:1218-1223.

35. Timmer, L. W., and Zitko, S. E. 1996. Evaluation of copper fungicides and rates of metallic copper for control of melanose on grapefruit in Florida. Plant Dis. 80:166-169.

36. Timmer, L. W., Zitko, S. E., and Albrigo, L. G. 1998. Split applications of copper fungicides improve control of melanose on grapefruit in Florida. Plant Dis. 82:983-986.

37. van Bruggen, A. H. C., Osmeloski, J. F., and Jacobson, J. S. 1986. Effects of simulated acidic rain on wash-off of fungicides and control of late blight on potato leaves. Phytopa- 
thology 76:800-804.

38. Vercher, R., Tadeo, F. R., Almela, V., Zaragoza, S., Primo-Millo, E., and Agusti, M. 1994. Rind structure, epicuticular wax morphology and water permeability of Fortune mandarin fruits affected by peel pitting. Ann.
Bot. 74:619-625.

39. Vicent, A., Badal, J., Asensi, M. J., Sanz, N., Armengol, J., and Garcia-Jimenez, J. 2004. Laboratory evaluation of citrus cultivars susceptibility and influence of fruit size on Fortune mandarin to infection by Alternaria alter- nata pv. citri. Eur. J. Plant Pathol. 110:245251.

40. Whiteside, J. O. 1976. Newly recorded Alternaria-induced brown spot disease on Dancy tangerines in Florida. Plant Dis. Rep. 60:326329. 